\title{
Interdependence between networks and member firms in the evolution of inter-organizational networks
}

\author{
LEANDER LUIZ KLEIN ${ }^{1}$ \\ Breno Augusto Diniz Pereira ${ }^{2}$ \\ 1 Universidade Federal de Santa Maria (UfSM) / Departamento de Administração,

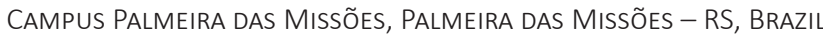 \\ ${ }^{2}$ Universidade Federal de SANTA Maria (UFSM) / Departamento de AdMinistração, SANTA MARIA - RS, BraziL
}

\begin{abstract}
Cooperation among firms through networks is a form to obtain a variety of resources. Over time, networks can become an exclusive provider of some resources used by members, leading to dependencys. This study is interested in this phenomenon, and aims to examine how firmnetwork interdependence grows throughout the development of inter-organizational networks. The research was conducted with networks that were in distinct stages of evolution (formation, development, and professionalization). Interviews were carried out with the presidents of the networks and two member firms of each network. The study identified an inversion in the relation of interdependence investigated, where the network is dependent of its members in the first stages of evolution and, as its governance and structure consolidate, members develop a dependency relationship toward the network and the benefits it offers.
\end{abstract}

Keywords: Interdependence. Dependence. Evolution of networks. Resources.

\section{Interdependência entre redes e empresas integrantes na evolução de redes interorganizacionais}

\section{Resumo}

A cooperação entre empresas na forma de redes pode ser considerada um mecanismo para elas conseguirem os recursos que lhe são faltantes. O fato a ressaltar é que os recursos proporcionados pelas redes podem se tornar únicos ao longo do tempo, e é isso que instiga a realização desse trabalho. O objetivo geral deste é verificar como se desenvolve a relação de interdependência rede-empresa e empresarede ao longo da evolução das redes interorganizacionais. Para tanto, realizou-se uma pesquisa com redes que se encontravam em fases distintas de evolução, sejam elas: Formação, Desenvolvimento e Profissionalização. Para coleta de dados, realizaram-se entrevistas com os presidentes dessas redes e mais dois integrantes de cada uma delas. Dentre os principais resultados dessa pesquisa, ressalta-se o fato de ter sido visualizada uma clara inversão na relação de interdependência investigada. Conclui-se que a dinâmica nos relacionamentos e governança da rede e sua evolução influenciam no delineamento da dependência das empresas com a rede.

Palavras-chave: Interdependencia. Dependencia. Evolución de redes. Recursos.

\section{Interdependencia entre redes y empresas integrantes en la evolución de redes interorganizacionales}

\section{Resumen}

La cooperación entre empresas en la forma de redes puede considerarse un mecanismo para que estas puedan obtener los recursos que les faltan. Vale resaltar que los recursos proporcionados por las redes pueden llegar a ser únicos a lo largo del tiempo, y eso es lo que instiga la realización de este trabajo, cuyo objetivo general es verificar cómo se desarrolla la relación de interdependencia red-empresa y empresared a lo largo de la evolución de las redes interorganizacionales. Para ello, se realizó una investigación con redes que se encontraban en fases distintas de evolución, como: Formación, Desarrollo y Profesionalización. Para la recolección de datos, se realizaron entrevistas con los presidentes de esas redes y otros dos integrantes de cada una de ellas. Entre los principales resultados de esta investigación está el hecho de haber percibido una clara inversión en la relación de interdependencia investigada. Se concluye que la dinámica en las relaciones y gobernanza de la red y su evolución influyen en el delineamiento de la dependencia de las empresas con la red.

Palabras clave: Interdependencia. Dependencia. Evolución de redes. Recursos. 


\section{INTRODUCTION}

In general, what motivates organizations to work together is the need to overcome the lack of resources, reduce market uncertainties, and take advantage of the opportunities that arise. In this regard, networks can provide a wide range of opportunities for the member firms to participate in activities that may complement their need for resources and generate benefits and organizational value.

The motivation of organizations to join and work together in networks is because they can increase resources, reduce the uncertainty of the market in which they are inserted, and seize opportunities. In this sense, networks can provide a range of activities that can complement the interchangeable enterprise resource needs, provide benefits and organizational value to members (CENTENARO and LAIMER, 2017; DEBOÇÁ and MARTINS, 2015), and network synergy (HERNANDEZ and SHAVER, 2018).

The fact to be highlighted is that the activities and benefits provided by networks may become unique and highly valuable for some members over the years, resulting in diverse outcomes in different aspects of the organizational function of these firms (MEDCOF, 2001). As inter-organizational networks evolve and become structured, these businesses can achieve a certain level of professionalization of their activities, providing unique advantages to the member companies, making them dependent on the network to which they belong. This is supported by Resource Dependence Theory, which states that organizations are in some part dependent on their environment, and they have to manage external resources (PFEFFER and SALANCIK, 1978). In other words, no matter how autonomous an organization is, it will always require third-party resources (RIBEIRO and COLAUTO, 2016).

In contrast, networks present some fragility with respect to their sustainability, or survival, especially at the initial stage of formation. To this point, Klein and Pereira (2016) explain that the greater the dependence of the network on key member organizations, the more susceptible the network survival is. This is because they have only a few members, and if one of them decides to leave, it puts at risk the continuity of the scheduled activities. Moreover, networks, when they are formally constituted, are organized into a shared governance structure (PROVAN and KENIS, 2007) supported by social mechanisms. Invariably, this governance mode requires participation, engagement, and commitment of all network members to be able to accomplish the planned activities and actions. Such dependency of the network on the member firms tends to diminish as the network grows and adopts more formal governance styles. Social factors and power of member firms generated from networks may motivate these firms to respond differently to the dependence logic of network formation and development (XIA, WANG, LIN et al., 2016), and this directs to understanding resources required for networking (DICKEL, HÖRISCH and RITTER, 2018).

Given these notes, the theme of this paper is the interdependence relation between networks and member firms in the evolution of inter-organizational networks, which was developed with the purpose of answering the following core question: What are the factors that influence the interdependence between the network and the member firms in the evolution of interorganizational networks? This question leads to an investigation of the aspects and factors that affect the interdependence between the partner firms and the network to which they belong and vice versa. Thus, the general objective of this study is to investigate how the interdependence relationship between network-firms and firms-network is developed along the evolution of inter-organizational networks.

Evaluating interdependence in the diverse network development stages meets the understanding of Popp, Milward, Mackean et al. (2014), who mention that a significant opportunity for the progress of studies and evaluation of networks lies in the conception and joint evaluation efforts and methods aligned with the network evolution stages, using the evaluation tools available and adaptation and development of new ones. Thus, it is intended here to advance in the comprehension of business collaborative dynamics through an analysis of network management, structure and governance, and dependency factors between member firms-network and network-member firms. As a managerial contribution, the study seeks to highlight the changes in the interdependent relationship that exists between the business partners and the network, in view of the benefits yielded by an improved performance, enhanced effectiveness, and specialization of the activities operated by the network and a shift in the governance structure. We believe showing how such evolution occurs and what supports it may contribute to an improved development and performance of networks. 


\section{Factors Influencing the Network's Dependence}

Since the network is a new formally constituted administrative entity comprised of independent firms that collaborate towards a specific goal, its dependence is basically related to the relational factors and behavior of the associated firms. This is how the network dependence on the member firms was studied and explored.

The first of the factors examined was the commitment of the network members, which is translated into the expectation that the other actor will fulfill its obligations, behave in a predictable manner, and act and negotiate fairly when the possibility of acting opportunistically is present (ANDERSON and NARUS, 1990). When the partner is committed to the relationship, he will make the best efforts for it to succeed (CASTRO, BULGACOV and HOFFMANN, 2011).

Andrésen, Lundberg and Roxenhall (2012) define the commitment as the loyalty of the representatives of the partner companies to the network as a specific unit. They mention there is a clear need for commitment to carry out network processes and activities and achieve positive results. Many studies mention and show that commitment is a key factor in the establishment of collaborative relationships and determines the prospects of long-term relationships (for example, SEATON, HOLM, BOTTORFF et al., 2018; GUNDLACH, ACHROL and MENTZER, 1995; ROXENHALL, 2011; ANDERSEN and MEDLIN; 2016).

The diverse kinds of relationships existing between firms are typically based on the commitment established by trust and reciprocity between the parties (GULATI and SYTCH, 2007). Trust is another key factor to building collaborative relationships and allows the partners to focus on and use their capabilities to promote joint outcomes, rather than pursue individual agendas (DIRKS, 1999). Perry, Sengupta and Krapfel (2004) define trust as the degree at which a focal firm believes the partner firm is trustful and has integrity. For these authors, trust is the belief that the partner will fulfill all obligations undertaken, while integrity is the belief that the partner is honest and does what is right.

Lewicki and Brinsfield (2011) emphasize reciprocity, expectations, or beliefs about the partner's intentions and the trustworthiness of others as essential to collaborative arrangements. Furthermore, Oliveira, Borges, Carvalho et al. (2016) emphasize that trust between companies must exist and is a way to anticipate the behavior of the other, facilitate knowledge of attitudes, exchange information and transactions.

Another factor that must be considered during the constitution and development of inter-organizational networks is the consensus regarding the objectives and goals to be attained. Ring and Van de Ven (1994) explain that building a vision and shared goals are vital in any collaborative relationship. According to Provan and Kenis (2007), achieving consensus about the network's general objectives, in the absence of hierarchy, encourages the network members to become more engaged and committed with the network and, therefore, more willing to work together. Carvalho, Wegner, Begnis et al. (2018) emphasize the development of profitable and productive interorganizational relations requires an alignment of objectives among the organizational members.

When setting the goals and objectives, there should be a balance between the members' and network's wishes. According to Andrésen, Lundberg and Roxenhall (2012), when the network's objectives are closely linked with the objectives of the member organizations, they are more likely to gain everyone's endorsement and support. This creates meaning for the members to cooperate and encouragement to commit themselves. It's needful to emphasize that Klein and Pereira (2014) relate the "lack of congruence and consensus between the members in relation to the objectives of the network" with the failure of this collaborative strategy (that is, the network).

These factors were assumed in this study as vital for network sustainability, especially because such networks are usually constituted of a few member firms. If one of them is discontent and decides to leave the network because of divergences or conflicts regarding the objectives or goals or any other reason, this may weaken the network and jeopardize its evolution.

\section{Factors Influencing Dependence of the Member Firms}

When one speaks about the organizations' dependence on the network to which they belong, one should remember the resources or capabilities necessary for the survival of the organization, which are mediated by the network. Such resources that are necessary to any organization are explored here as key aspects for its competitiveness, which leads to its dependence on the actor who provides such resources, in this case, the network. 
In this regard, building and developing inter-organizational relationships are often driven by the search for efficiency and better economic outcomes if compared to the outcomes of a firm operating independently. Inter-organizational networks are a suitable organizational alternative, especially for small-size firms. These, in turn, have, as a competitive and successful alternative, the market control, which is mainly attained by offering lower prices of products and services (PERROW, 1998). In contrast, by means of cooperation, small firms interact with each other, seeking to boost bargaining power and costs reduction of some activities, which may help them compete with larger business firms.

Waarden (1992) explains that economies of scale and bargaining power gains give member companies the possibility to enter business agreements with exclusive conditions (not possible before) and enhance the bargaining power in distinct economic relations. This provides to the partner firms of networks a competitive advantage that did not exist before. Jarillo (1988) explains that a firm that is part of a network may incur lower costs because it reaps economies of scale (or any other source of efficiency) from the associated firms that other competitors cannot achieve on their own. Sadowski and Duysters (2008) emphasize reducing risks associated with the business, given that they act together.

Another aspect explored in networks is learning. Popp, Milward, Mackean et al. (2014) mention learning is a key process in networks, which is closely linked to building and exchanging knowledge, driving organizations to tacit strategies (IDRESS, VASCONCELOS and ELLIS, 2018). They explain that learning is inherent in networks by the fact that they are established to operate differently than other traditional organizational forms and to consider problems that cannot be addressed by a single organization. Information exchange is essential to this process. Knoben, Oerlemans, Krijkamp et al. (2018) explored and explained information accuracy like a differential to organizational networks and found organizations can benefit themselves and obtain strategies from information accuracy differentials. From this perspective, business networks, as Kogut (1988) views it, emerge as a strategic response to environmental changes and under the perspective that their members will acquire skills, knowledge, and technological competence via learning.

Inherent to learning is the innovation process in inter-organizational networks. Innovation and the previously mentioned knowledge and learning exchange functions are closely related, because they contribute to the specialization of activities and tacit knowledge, which are particularly valuable. De Rolt, Dias and Peña (2017) argue that networks can provide the complementary knowledge crucial to innovation and can become the ideal mechanism to promote innovation and competitive positioning. Westerlund and Rajala (2010) point out there is a positive relationship between a firm's innovation and collaboration in networks. So, although networks are usually formed for other reasons, innovation becomes the driving force to their sustainability (PEREIRA, VENTURINI, WEGNER et al., 2010). Along with this, Provan and Huang (2012) argue innovation is an important function of networks as it is fundamental for solving complex problems. Innovations achieved in inter-organizational networks, whether through learning or specialization and standardization of certain activities and/or processes, lead to other key factor, organizational legitimacy.

According to Suchman (1995, p. 574), legitimacy can be defined as a "generalized perception or assumption that the actions of an entity - organization or organizational network - are desirable, proper, or appropriate within some socially constructed system of norms, values, beliefs, and definitions." This legitimacy is fundamental in the success of one organization and is related to the perception generated and socially constructed with clients, financiers, and organizations inserted in the institutional environment of the organization/network (PROVAN and LEMAIRE, 2012; ANDRÉ, 2013).

In the inter-organizational context, Dimaggio and Powell (1983) mention, when a firm participates in a network relationship, they are perceived as "great" in their business field, besides receiving more credit and recognition from the public. This, ensures more legitimacy to the organizations' actions and re-dimensions the importance of the business in its institutional context. For them, agents interested in establishing relationships with a given firm generally expect this firm can prove to have political support, essential resources, and financial stability. Several studies have developed the understanding that, working in collaborative networks, it is easier to convince and get support from internal and external interested parties for the activities developed due to the legitimacy reached by the group (MCGUIRE, 2006; MILWARD and PROVAN, 2006; PROVAN and LEMAIRE, 2012; PAQUIN and HOWARD-GRENVILLE, 2013).

\section{Proposing an Interdependence Framework between Networks and Organizations}

As can be seen in the two previous topics, analysis of dependence is focused on the two following general approaches: (1) how social interaction mechanisms influence the network's dependence on the member firms; and (2) how the benefits provided by joint activities, typically associated with performance (bargaining power, learning, innovation and specialization of network activities, and legitimacy), determine the dependent relation between firms and network. These factors interact in the cooperation context and are discussed in this study as networks-firms interdependence. Figure 1 illustrates the proposed framework. 
Figure 1

Framework of network-firms interdependence factors

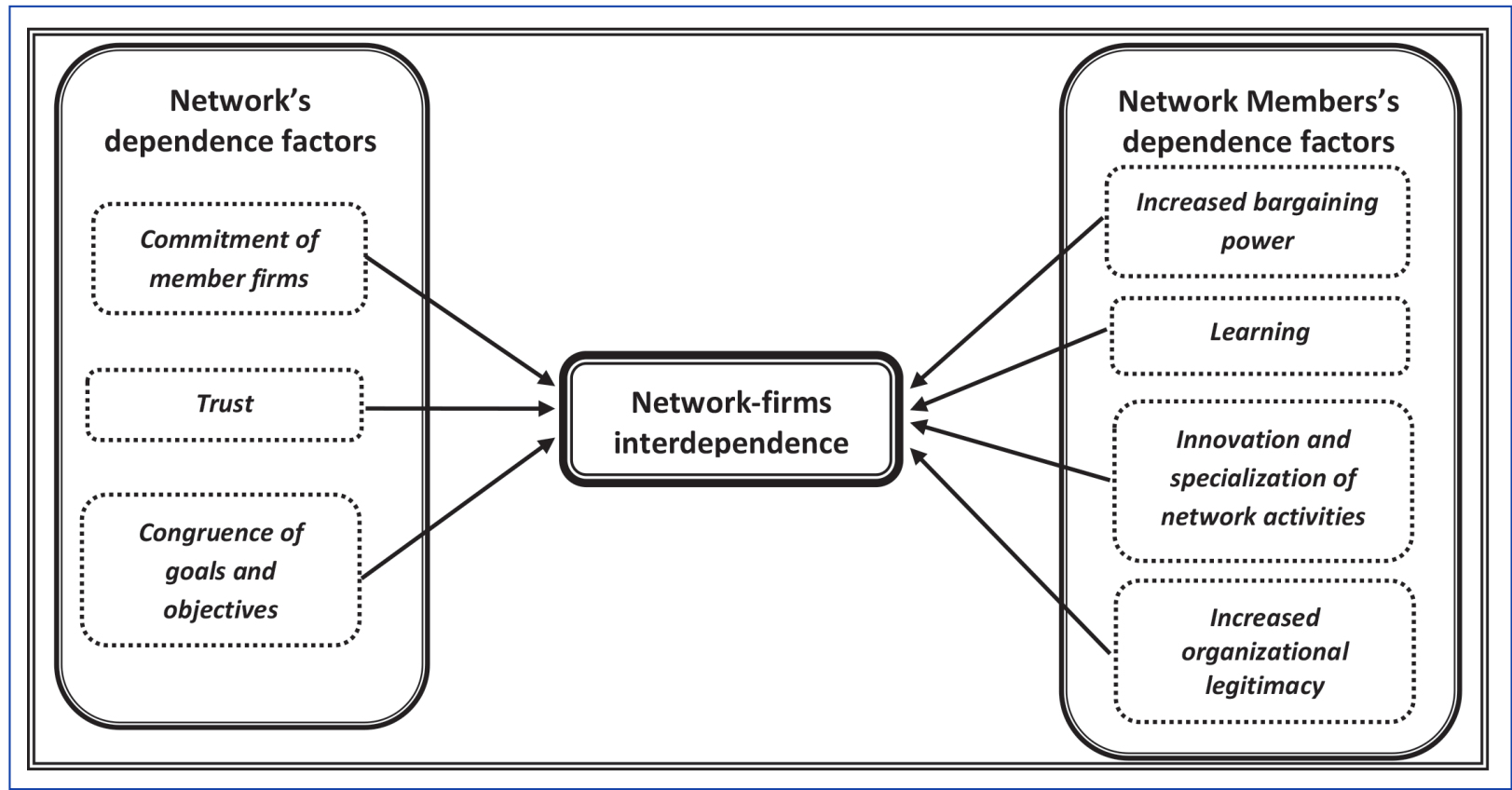

Source: Elaborated by the authors.

The proposed framework aims to help understand the factors used in this study to describe the interdependence between networks and member firms. Specifically, combination of the three factors shown at the left side of Figure 1 would be conducive to network dependence on the member firms. On the other hand, the four factors on the right side of the figure have influence on the firms' dependence on the network. The arrow at the center of the figure indicates an interaction among these factors along the evolution of networks, and these factors determine the interdependence relationship between networks and their members.

The perspective of the networks' evolution over time is added to this framework and will be defined in the study method. Assessing networks' interdependence according to their evolution stages is in agreement with Popp, Milward, Mackean et al. (2014), who mention a significant opportunity for the progress of studies and assessment of networks lies in the conception and combination of assessment efforts and methods aligned with the network evolution stages, using all instruments of assessment available and the adaptation and creation of new ones.

\section{Method}

This paper consists of a descriptive study, because we have well-defined constructs. To develop this study, organizational networks were investigated, which were, at the time of data collection, at three distinct stages of evolution: Formation, Development, and Professionalization. Each of these stages was identified according to the variables described in Box 1 . These variables were taken as criteria to assign the networks in each stage of development. These stages of network development were establish based on the seminar article of Provan e Kenis (2008), but some adjustments were set to adopt each stage to the reality in Brazil. 


\section{Box 1}

\section{Criteria addressed in the analysis of the networks' stages of evolution}

\begin{tabular}{|c|c|c|c|c|}
\hline Variables & Network Formation & Network Development & $\begin{array}{c}\text { Network } \\
\text { Professionalization }\end{array}$ & Reference authors \\
\hline $\begin{array}{l}\text { Governance } \\
\text { mode }\end{array}$ & $\begin{array}{l}\text { Shared, self-managed } \\
\text { governance }\end{array}$ & $\begin{array}{l}\text { Group of leading firms } \\
\text { with the support of an } \\
\text { administrative entity }\end{array}$ & $\begin{array}{l}\text { Network Administrative } \\
\text { Organization (NAO) }\end{array}$ & $\begin{array}{l}\text { Provan and Kenis } \\
\text { (2008); Popp, } \\
\text { Milward, Mackean et } \\
\text { al. (2014) }\end{array}$ \\
\hline Leadership & $\begin{array}{l}\text { Centered on member } \\
\text { firms in general }\end{array}$ & $\begin{array}{c}\text { Shared by leading firms } \\
\text { and the administrative } \\
\text { entity }\end{array}$ & Centered on NAO & $\begin{array}{l}\text { Provan and Kenis } \\
\text { (2008); Dwyer, } \\
\text { Schurr and Oh } \\
\text { (1987); Silvia and } \\
\text { McGuire (2010) }\end{array}$ \\
\hline Decision making & $\begin{array}{l}\text { Decentralized in member } \\
\text { firms }\end{array}$ & Partially centralized & $\begin{array}{l}\text { Centralized and } \\
\text { hierarchical }\end{array}$ & $\begin{array}{c}\text { Provan and Kenis } \\
\text { (2008); Albers } \\
\text { (2010); Popp, } \\
\text { Milward, Mackean et } \\
\text { al. (2014) }\end{array}$ \\
\hline $\begin{array}{c}\text { Management of } \\
\text { activities }\end{array}$ & $\begin{array}{l}\text { Supported by social } \\
\text { mechanisms }\end{array}$ & $\begin{array}{c}\text { Centered on leading firms } \\
\text { and the administrative } \\
\text { entity }\end{array}$ & Centered on NAO & $\begin{array}{l}\text { Provan and Kenis } \\
\text { (2008); Wegner and } \\
\text { Padula (2010) }\end{array}$ \\
\hline $\begin{array}{l}\text { Relationship } \\
\text { framework }\end{array}$ & $\begin{array}{l}\text { Incipient and disperse } \\
\text { - there are strong and } \\
\text { weak bonds }\end{array}$ & $\begin{array}{c}\text { Definition of strong and } \\
\text { weak bonds by establishing } \\
\text { trust-based relationships }\end{array}$ & $\begin{array}{l}\text { Maintenance of strong } \\
\text { and weak bonds and } \\
\text { informal relationships }\end{array}$ & $\begin{array}{l}\text { Provan and Kenis } \\
\text { (2008); Granovetter } \\
\text { (1983); Provan and } \\
\text { Lemaire (2012) }\end{array}$ \\
\hline
\end{tabular}

Source: Elaborated by the authors.

Based on these criteria set in Box 1, we conduct interviews with the presidents of the networks that we selected based on their willingness to participate in the study. So, by conducting these interviews, we could identify, classify, and certify which phase of evolution each network selected was in. Specifically, we classified, by these coding procedures, three networks at the stage of Formation, four networks at the stage of Development, and three networks at the stage of Professionalization.

Once done, we interviewed the president of each selected network again to obtain data to verify the dependence of networks upon their member firms. To do this, we used an interview protocol based on the variables shown on the left side of Figure 1 and its correspondent literature.

A third stage of our study was to interview businessmen (members) of each network selected. These member firms were interviewed to obtain their opinion on their dependence on the network and a second interview protocol was defined considering the variables shown on the right side of Figure 1 and its correspondent literature. At this stage, we decided to interview one recent member (less than 3 years in the network) and one old member (more than 3 years in the network) of each network, performing a total of 20 interviewees.

Thus, 10 presidents of organizational networks and 20 executives of member firms were interviewed. In the analysis of the interviews, the respondents were identified by codes to protect their anonymity. So, the presidents were identified as "Pres," the network member executives by "M." To indicate the stage of evolution of each network, the code " $\mathrm{F}$ " was added when the network was at the Formation stage, " $\mathrm{D}$ " when it was at the Development stage, and " $\mathrm{P}$ " when it was in the Professionalization stage. Finally, the presidents had identification numbers from 1 to 4 and the member firms from 1 to 8 ( 1 to 4 for recent members and 5 to 8 for older members). So, 'Pres $D$ 3', for example, identifies the views, opinions or responses of president \# 3 of a network at the Development stage.

Qualitative content analysis was used for the research analysis. According to Bardin (2010), this technique can be considered a set of analysis techniques that seek to describe, by means of systematic and objective procedures, the interviewees' responses, the message content. In general, Flick (2009, p. 291) states that content analysis "is one of the classical procedures for analyzing textual materials no matter where this material comes from." 


\section{Results and Discussion}

In this section, data resulting from the empirical research conducted are presented. Analysis of these data was made comparing the three stages of evolution defined in the study method.

\section{Analysis of the network dependence relation}

In this subsection, the factors that generate network dependence upon the member firms are analyzed. The first factor investigated with the networks' presidents was commitment. This factor is mentioned by scholars as one of the key factors required for the creation and maintenance of inter-organizational relationships.

Specifically, in the networks that adopted shared governance, as is the case of the networks at the Formation stage, management of the networks relies on the members' commitment and engagement. At this stage of evolution, networks usually adopt this self-managed governance model, because, as stated by Olson (1999), it is a governance mode that can be relatively successful in small groups that may exert more control on the members, exert pressure to participate, and have the advantage of including all participants. However, it requires the commitment of all those responsible for the management of the networks' internal relationships to be effective. This is what makes the network dependent on the commitment of the members at this stage.

Two of the presidents of networks at this stage mentions:

We had to talk to the staff and highlight the issue of the importance of commitment, that there has to be this commitment on the part of everyone, otherwise our network can not function and grow (Pres F 1).

Such commitment is vital. It is important that people be engaged in participating, with the transparency it must have. It is a group that is being formed. It is no use saying, we will appoint a manager and he will run the network and the network will solve all problems for us. It doesn't work. People have to participate, be engaged, committed (Pres F 3).

To succeed at this stage, the network's activities should be proposed and conducted with the assistance of the member firms, and in this regard, their commitment is vital. This is what the interviewed presidents emphasized, as can be seen in the above statement.

In addition to the members' engagement with the network operations, another factor largely cited in the literature about networks formation and development is trust. At the stage of formation, specifically, trust is one of the social mechanisms used to ensure effectiveness of shared governance. Provan and Kenis (2007) state trust is key to the performance and effectiveness of the networks that adopt this governance mode. The presidents said trust is a key factor in network continuity.

People will have to trust their peers because, like it or not, everyone knows what the others are producing, how they work, and who are their customers. So, when you are on vacation, I will deal with your customers, which in the past did not happen. So, trust is key in this kind of business that we are working on. The network needs it, otherwise we will not succeed in selling our idea (Pres F 1).

Yes, I know I can buy a lot of stuff on behalf of everyone, and know what the other will pay, this is essential to network, even more like ours. Without it, we would not be doing anything. So trust is very important. I believe the network depends a lot on it to exist (Pres F 2).

We have confidence in each other. There is transparency, and for a network, for me, if it does not have it, it has no network, there is no network (Pres F 3).

Trust between the members at this stage is not merely the expectation that the other undertakes an established promise, but that it helps achieve the expected results (CONKLIN and TAPP, 2003). Such trust between the network members relates to aspects, such as agreements about the obligations and rules for actions, exchange of information, and their commitment to perform the joint activities without the need of control mechanisms.

Another issue that was asked to the network' presidents was about the congruence, or agreement, of goals and objectives. This aspect has been assumed as a driving element of the network's proposals and expectations. Some studies emphasize 
this aspect, underlining the importance of establishing criteria for the selection of partners because the network specific resources and objectives should coincide (MOELLER, 2010).

In the networks at the formation stage, one can see a clear dependence relation of the network upon the member firms.

In our network, this is quite clear, because if you fail in achieving your goal, you will not earn the extra pays from the insurance companies. [...] So, our goal is very clear. Everybody has to understand this objective and work for it, so that everybody can receive more and more. If the member does not understand it, it won't work for him or for the network either (Pres F 1).

It is essential, yes, very important. If the guy does not understand why we got together, why would he want to stay with us? Until that time, our network did not work out. (Pres F 2).

It is worth noting the self-management mode of governance probably works better in networks comprised of mutually dependent organizations and where there is compatibility and complementarity of objectives. This aspect is crucial for network effectiveness at this stage of evolution.

An initial analysis of these three factors in the networks at the formation stage clearly shows the networks' dependence on the members to perform their activities and for their continuity. This is due to the shared governance model adopted by these networks and the small number of members they had. The networks at this stage had 4, 6 and 9 members. So, if any of the members could not commit, carrying out the proposed activities and their management style would be compromised.

However, as the network grows, develops, and evolves in the organization of their activities, such clear evidence is no longer easily perceived. In a comparative analysis with the other stages of evolution, as defined in this paper, one can see that such dependence decreases and practically stops when the network reaches the professionalization stage.

Regarding commitment, two of the presidents of networks at the Development stage says:

We should have more people engaged and committed. Many people in our network only wait for things to happen. [...] There are people who do not arrive on time for meetings. This is something that lacks in some people, but we have been able to make things happen, though. Other members help us and move the network ahead (Pres D 3).

Commitment of the members does not always happen. The group got big, and not everyone gets engaged like we expected. This is one of the problems of our network. We've been in the market for 9 years now, we have network problems, and one of them is this lack of commitment. But we can continue anyway (Pres D 1).

These reports show that, differently than networks at the formation stage, non-commitment of a member does not significantly compromise network operations as a whole. The respondent mentions the network manages to proceed with its activities if one or another member is not committed.

At the Professionalization stage, the presidents interviewed were even more emphatic regarding non-dependence upon the members.

The network, as we have organized it, with a structure consisting of directors and the board, this will never break up because we no longer will depend on the associated members, even if they do not commit themselves (Pres $P$ 2).

The network does not care about this if someone does not compromise, because it has a structure that, if it leaves one or two, the others can keep well. And the network always works with $x$ value in cash, even to answer those questions there (Pres $P$ 3).

As stated by these presidents, the network structure is organized in such a way that, even if the members fail to commit to the network, it will be able to go on with its operations.

This is closely linked to the benefits provided by these networks, which will be described in the next subsection. In other words, the activities organized by the most advanced networks yield benefits that are so important to their members that they ultimately get committed. That is why the network's dependence in this aspect diminishes as it becomes structured, organized, and evolved. 
The same analysis can be made regarding trust. Some presidents of networks at the Development stage comment:

If there is no trust between one member and the network, at this stage, our network will not end. There is this member that I told you before, which we end up turning a blind eye to him, for the things that come from him (Pres D 4).

I can say, then, that the vast majority trust each other. Of course, we will do everything we can to trust everyone and not to leave the network, but this doesn't happen [...] No, the network does not end up leaving one, but we want to keep it together (Pres D 1).

Some president of networks at the Professionalization stage report:

Today, the network is stabilized. Dependence, today, I am sure, regarding my supermarket, dependence of the supermarket on the network is much greater than the network in relation to my supermarket (Pres P 1).

There is the owner, who has his own pharmacist, and does not want to know about the other. He takes advantage of what is good for him, what is bad he does not even give hours. That is our great difficulty, but doing what. So we can't trust this guy, we can not (Pres P 2).

Based on these reports, one can see trust among members is no longer necessary to maintain the network active in the market. As the network evolves and as long as the resources and benefits that are essential for the member firms are delivered, trust is no longer a need for them but rather the activities and opportunities produced by the network. In general, as the member firms are no longer part of the network governance framework and move away from the network management, they must trust that the network can be the mechanism of generation of the benefits and resources they need.

Finally, as the responses on the congruence of goals and objectives were analyzed, we could see the network's dependence upon the members also decreases, as the following statements shows:

If someone is pulling to the opposite side, there is no reason for the network to exist for that person. If they choose the other side, we even try to pull them back, to the collectivity. But if they do not want to come, then there is nothing we can do. They follow their own path, we follow ours and will seek in the marketplace a company or more that share the same vision of ours (Pres D 2).

So this question of everyone thinking in a similar way, having what the network looks for in mind, is rather something that helps a network a lot without a doubt. I and other comrades, we hit a lot on top of that, and we have achieved a lot, many courses for us, even if some do not participate and do not have this in mind (Pres D 3).

We respect the differences, because we have centennial stores. But for us, it is important to add, because the more tenants we have affiliated within a profile of our network, the greater the purchasing power, the greater the bargaining power with suppliers, the more options we have when we do a promotion. The member has to understand this and fit the profile of the network, otherwise we do not accept it or we disconnect it (Pres $P$ 3).

Based on these reports, one can understand that, as the network develops and evolves, it attempts to adapt the profile and goals of the associated firm to the network goals. Shipilov, Rowley and Aharonson (2006) emphasized in their studies the need that potential members of a network have to fit their operations and goals to the network and have a profile that matches the cooperation culture. However, if this does not happen, the network activities, especially at the professionalization stage, will continue even if a member does not fit that profile and goal.

At the network's Development stage and particularly at the Professionalization stage, one can see, in general, these analyzed factors do not become less important than at the Formation stage. They continue to be important, but the network no longer depends heavily on them to run the business. As the number of members of the network increases and the activities become more structured and better organized, if one or another member decides to exit, it will not cause any damage to the operations because the remaining partners will provide the necessary support to the network. 


\section{Analysis of the member firms' dependence}

With regard to the aspects that affect members' dependence on the network, the factor that was questioned of the interviewees was bargaining power. This factor is mentioned in several studies as the main competitive advantage that network members would gain. Bargaining power, as mentioned in the theoretical framework, ensures members more capacity to obtain lower prices for their raw materials or goods because, when they buy larger quantities as a group, suppliers are pushed to reduce prices. This is why this factor is examined in this study as an influencer of the dependence of the firms on the networks.

However, in the networks at the Formation stage, this factor was not considered as something that would generate dependence of the firms upon the network. The statement of some respondents shows:

As we are small firms, none of us can buy large quantities alone. So, when we see that there is a material that we use a lot, we buy it together. Except in this case, when we need small amounts of material, then we buy it independently, off the network. So, yes, we have more bargaining power when we buy together, but we do not depend on the network for that (M F 3).

So it's a good thing for us. But, like you asked me before, what would happen if the network ended... I would buy it myself. I have a credit in the market and my company would never end if the network ceased to exist ( $M F 1$ ).

So with the union, we got better, more competitive rates, and we became more competitive in the market. That's because, before, we only had the argument to offer more complete insurance, and today we also have better prices. It is something that when we have more members will make us stronger and competitive, and with a link to the network, it will be difficult to dissociate (M F 4).

So there are few things, because we already know our customers and the customers of others in our city, what the other buys, in that my product differs from the other. My company would not end if the network did not exist, because we already structured ourselves individually, and that would be quiet (M F 6).

Based on what these respondents stated, we can see that business networks actually are an advantage in this aspect but not to the extent of creating dependence upon it. Most of the respondents emphasized, although this advantage makes a difference to them, their firm and businesses would not terminate if they lose this benefit in case of dissolution of the network.

However, in networks at the Development stage and more specifically at the Professionalization stage, the members appraise this factor differently. As the network develops and grows, the probability that the members will buy equipment, tools, courses, and raw material together, as a group, becomes more effective, creating an opportunity for them to negotiate prices, delivery dates, and payment conditions with suppliers. The reports of some of the members summarize this situation:

So the difference my company made to being in the network is at least a five percent difference in value compared to if I was not on the network. If I had not been on the network, I certainly would not have achieved those values. So, this is an essential thing for me and that the network provides me (MD 7). We have made purchase packages of electronic injection equipment, scanner, and others. There was one time we bought 7 equipment, and besides a discount, we had a deadline. So, the network gives this advantage to the associated, if compared to the independent workshop, right (M D 6).

The economic aspect, then, you can imagine more than 700 stores all of them buying together, negotiating with the supplier. You have much more bargaining power than if you were independent and working all by yourself. Then, well, no doubt about it, an association, as it is the case of our network, is the best way for small businesses, which is my case ( $M P 1$ ).

Let's say that we buy 100,000 units, the supplier gives me 10\%, we buy 500,000 units, I get 15\% off, 1 million units gives me 20\%. The small pharmacy can not afford to buy 1 million. But we are 720 stores, 
and 1 million units for us is bait. You understand me? So that's the great dependence of independent pharmacies today (M P 5).

These conditions create a purchase condition that an individual firm could not have, which is essential to maintain the business. As a result, these firms become dependent on the network to which they belong.

Another factor asked of the respondents was learning and information exchange between the members of the network. Learning with other members sometimes happens by operating with another organization or in achieving a common understanding of a problem and getting consensus on how to handle it (GRAY, 2000). Such a partnership with other members may effectively enhance learning and one's skills in providing services and activities, as well as in offering their products, so they can compete in the market effectively.

The members of the networks at the Formation stage cited information exchange and learning in different ways and as something beneficial for them. However, nothing was said that could be understood as having a dependence relation of these firms with the network. Some of the members mention:

We exchange ideas, talk a lot about work, but nothing that makes us dependent. We do not depend on the network for anything, anything at all (M F 2).

So it's a good thing for a partner to even have the contact that we have between us, but nothing much like this (M F 6).

So, about that learning you said, I'm not network dependent. But indirectly I would continue to exchange information with them, continue to clear my doubts with them ( $\mathrm{F} 3$ ).

Studies on networking have shown that business networks can build an environment where the members may exchange experiences, work practices and management, knowledge and information in general to be added to the operations of these firms, especially competitive advantages to the members in the form of innovation and learning. However, Schulz and Geithner (2010) explain that learning and development in networks depend on key factors, including the composition and number of members and sufficient operational resources to enable them to develop new ways of working. In general, some elements are necessary for a member firm to obtain real competitive advantages through learning and actually make them dependent on the network.

Regarding the members of networks at the Development or Professionalization stage, learning provided by the network through courses and lectures is vital and provides new knowledge to the members. These are key issues with a direct impact on the businesses of these members. Some of them say:

This is the greatest achievement that we have, and if I have pleasure in being in the network, it is in that sense, to have a doubt or not to know something and the staff know how to give you information on how to do. The content, the exchange of information, this for me is essential (M D 2).

One of the main reasons for forming the network is the search for information and the updating of the profession. Look, I would say that this is more important than buying together, because we need to improve our activity, to stay current in our day to day work (M D 6).

We will have courses on taxes, laws and inspection. There are aspects that affect our business. Inspections, such as the sanitary surveillance inspections, are a commonplace, we need to learn about it. To give you an idea, an invoice today requires 14 different taxes to be paid (M P 5).

These reports show learning via networks is a factor that ensures competitiveness for the members, especially regarding information and other market situations, as emphasized by M P 5. Learning in networks provides faster and easier access to information and makes the member firms and their collaborators knowledgeable about management techniques and procedures that are key to run their businesses more effectively. Information on taxes, laws, and inspections that companies have to be concerned with, as mentioned by $M P 5$, they would hardly know so easily if they were not part of a network.

Associated with the aspect discussed above is the specialization of activities and innovations provided by networks. This is one of the major forms of building competitive advantages in firms that operate in networks. As defined in this study, innovation 
can be understood in diverse ways, as the introduction of a novel product into the market or a new method of production or the development of a new source of raw materials or goods or the opening of a market or business (SCHUMPETER, 1911). Its main characteristic is related to commercial or organizational application of something new or unknown to the company until then.

The network's members at the Formation stage, however, did not mention this factor. They only mentioned that the networks were not yet able to innovate and introduce specialized actions or activities to the businesses. Two of them say: "Well, in this aspect each one has its own way of working and each one deals with their difficulties on their own. There is not much relation with the network (M F 1)". "Even if we have our own focus, we get information from someone in the group who made an improvement, which he did in a different way. Nothing very essential for us (M F 5)".

In the Development stage and, especially, at the Professionalization stage, respondents were more emphatic and indicated situations where network innovations make firms dependent. Here are some reports:

We have in the network, they are professionals who have the technical capacity to give courses to our employees. For example, we have a member of the network, that he is an authorized assistant of Bosch and he is able to give course of ultimetro, the electrical part, for our employees. [...] Even so, the 5S, we apply a lot in our companies, like the sense of cleanliness, sense of organization, that makes the day to day of each one a lot more organized (M D 3).

In this aspect, the network helped us on the system. This system allows us to manage inventories, losses, in the control of expiration date of products, control of medication lots, and traceability. All this is done today in my store; I can control all this. This could only be possible after I joined the network and had access to this system, which allows me to do all this. Then, not only in purchasing I am dependent (M P 1).

In the network system has everything too. It has a payment term, is valid, has the type of delivery, whether it will be delivered at the store or at the central warehouse, if the note is from the network or if it is invoiced directly to us. It has these details right there. It's something the network provided me with, and I do not see how I can work without it. It's too much (M P 2).

We take care of your request at your house, you do not have to leave the house. We sent you a little machine to pay with the card in the house. So, these facilities we put in and are creating new, different things that others do not have (M P 5).

What must be pointed out regarding this finding is that the generation of resources and new activities, which the members would hardly achieve if they were not in the network, is often obtained as the network specializes its activities and innovates. The literature on networking and innovation shows the firms that belong to networks are more innovative than those that operate independently (AHUJA, 2000). However, to achieve innovation, sometimes is necessary to structure the network, organize activities, and reach the basic objectives defined.

Finally, the last factor studied in this subsection relates to the organizational legitimacy acquired by operating in a network. It refers here to the outside legitimacy achieved by the organization, the one related to the perception of their stakeholders. The core issue investigated here is how better the firms are perceived by the market and how better the clients, suppliers, investors, and others view their image and reputation.

The members of networks at the Formation stage mentioned elements that could be the first step to build legitimacy. Two of them said: "We managed to standardize some activities in an attempt to build an identity for the network. We had uniforms made for everyone, a logo sign for the firms to use and identify the network, but it kind of didn't work, and everybody now does things as they please. (M F 3)." "So we are creating an image in this sense, but not that we are dependent for it, even for the time that we have to market. (M F 4)". These are long-term practices that, as the network becomes structured and organized, the stakeholders will recognize and help them build an organizational legitimacy. However, no respondent mentioned anything that could indicate members' dependence on the network.

Legitimacy is a symbolic resource that the member firms did not have before joining the network. It is constructed by the actions of the network, by the relations established with the stakeholders, and by the system of norms and values built and sustained by the network. At the Professionalization stage, the respondents' reports indicate the consolidation of the network legitimacy, which has a direct impact on the businesses of the member firms. The report of some members of these networks shows: 
I think, that's a good thing for both sides. For the network, people go by and see: 'bah, the company is also part of the network'. And for me, I end up getting more image than I had before, people come to see my company by the work of the network. So, now, it's a double exchange, it's good for me and it's good for networking too (M D 8).

They seek the network because they know the role it plays, its reliability and the conditions it offers. Our network has always valued it $-100 \%$ of payments are made on time, our reliability, it does not let any bill unpaid when due, or any delay. These are things that we always preached, and our suppliers know it; so, for this reason they bring us good deals (M P 2).

Yes, for example, we have a great respect for the suppliers, and them for us. I remember when we arrived at fairs and everyone with T-shirts from the net, they say: "Oh, the network gays has arrived..." [...] So, when you are part of the network, like we today, you have a recognition by the suppliers and also by the tenants who are part of it (MP 6).

Today, we know that the network is recognized nationally, because the managers come from the national level here wanting to enter Rio Grande do Sul to sell some product in the region. They look for the network because they know the role of the network and know how serious the network has and the conditions that the network has (M P 5).

The fact that organizational legitimacy is built as the network evolves explains why the networks at the formation stage do not have this symbolic asset. Furthermore, Provan and Sydow (2009) state elements, such as the capacity to obtain resources and have a sound financial performance, contribute to the legitimacy of inter-organizational relationships. According to Human and Provan (2000), acceptance of the network by the members and outside actors as a provider of status and credibility, based on the commitment and support to key resources, builds legitimacy and determines whether the network will survive in the long term as an inter-organizational form of business.

\section{FINAL CONSIDERATIONS}

The general objective of this paper was to investigate how network-firms and firms-network interdependence is built along the evolution of inter-organizational relationships. Based on the findings of this research, we could have insights into this objective.

First, we could see a clear inversion of the interdependence relation between the parties. Networks, at their initial Formation stage, are dependent upon their members regarding social mechanisms of control, such as commitment and trust, as well as the congruence of goals and purposes. As Xia, Wang, Lin et al. (2016) argued, social factors of network members stimulate and motivate firms to respond to the dependence logic and to needs that come over during the cooperation formation. Furthermore, at this stage, the networks have a small number of member firms and often adopt the shared governance mode to run their operations. Especially in this governance mode, the investigated elements are critical to the effective performance of the proposed activities (PROVAN and KENIS, 2007).

In the studies by Tubin and Levin-Rozalis (2008), they describe that cooperation is built through social interaction over time, with a compatible corporate culture and shared norms. This goes in consensus to Dickel, Hörisch and Ritter (2018) that describes that social values and interaction give to companies a similar understanding of resources required for networking. Besides that, it would increase trust between cooperation partners and exchange of information, like Oliveira, Borges, Carvalho et al. (2016) emphasized.

However, as the networks evolve, the number of members increases, they begin to use more formal governance styles (such as those that adopt NAOs) that are more likely to become more efficient than the networks that adopted the shared governance pattern (PROVAN and KENIS, 2007). In such governance modes, the networks' dependence on the members decreases, as could be seen in the present empirical research. At these more evolved stages, the networks provide benefit s and fit members resource needs (like those described by Centenaro and Laimer (2017) and Deboçá and Martins (2015)) that they would not get alone in the market. The challenge the networks have at these stages and with such governance styles relates to the competence necessary to meet the members' needs for resources. 
Here, it is important to note that the evolution of the network and the use of more formal governance structures go hand in hand. In other words, to maintain the activities and achieve the planned objectives, greater efforts of time, organization, coordination, and control are required, increasing the level of managerial competencies required. As a result, networks tend to adopt more formal modes of governance, such as lead organization and network administrative organization (PROVAN and KENIS, 2008). With respect to the development of governance structures, Isett, Mergel, LeRoux et al. (2011) mention a trend described in the literature that networks start with a common and informal structure and tend to become more formal over time.

Figure 2 was created to illustrate the interdependence difference and shift as investigated in this work. It shows the "behavior" of the interdependence between the networks and member firms according to the stages of evolution of the networks under study.

Figure 2

Network-firm interdependence

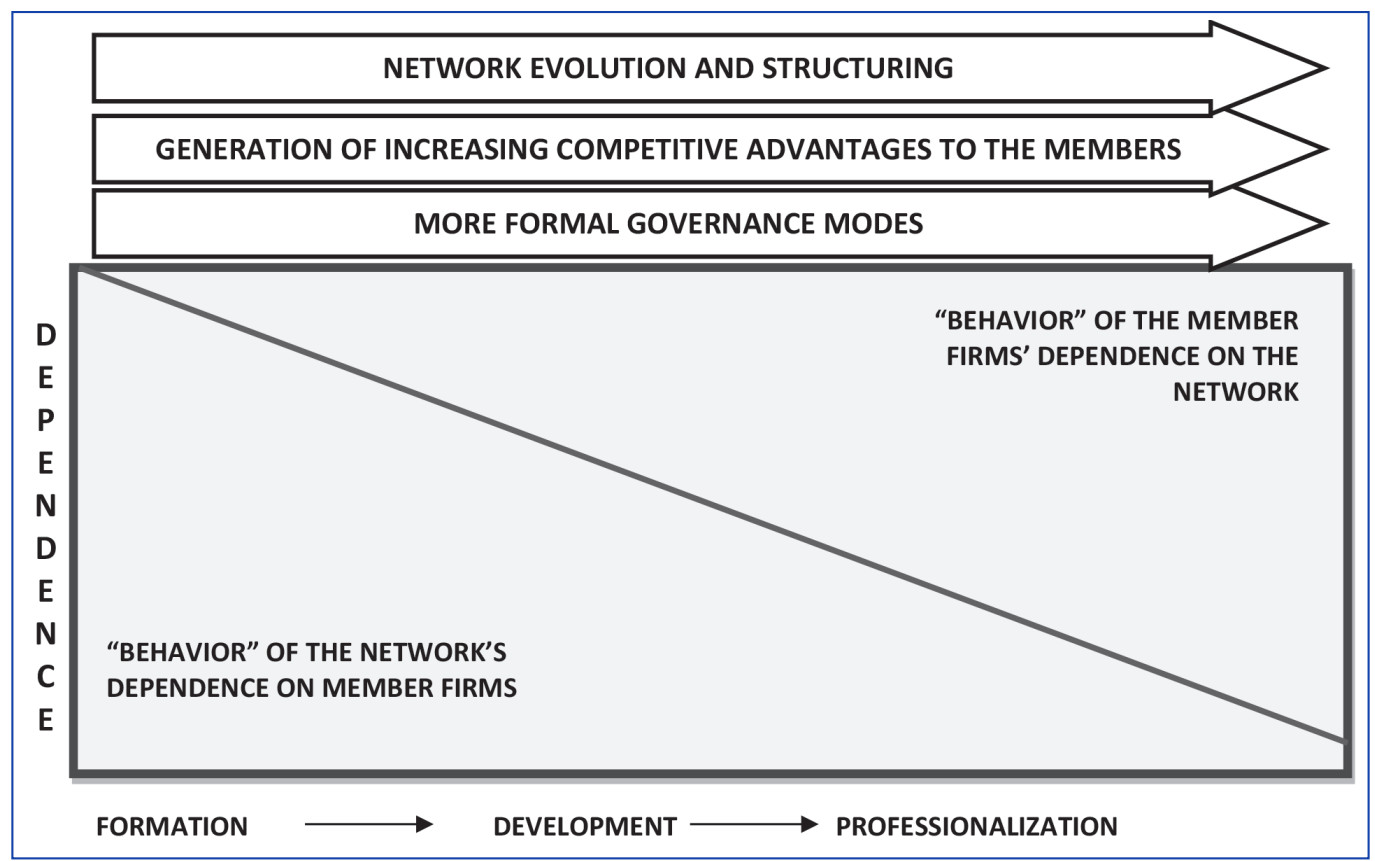

Source: Elaborated by the authors.

What we intended to represent in Figure 2 is precisely what was seen in the presentation of results, i.e., an inversion of the interdependence between the networks and the member firms. In other words, dependence of networks is high at the Formation stage and decreases gradually as it evolves. With the member firms, it is the opposite. Their dependence increases as the network evolves and becomes more structured.

More specifically, the response the network provides as it evolves concerning the resources the member firms need causes the inverted dependence of the firms. When the firms join the network, they are seeking opportunities to improve their businesses from the benefits the network provides. However, when the network begins to improve its organization and managerial structure and contribute with unique resources to the member firms, the members become progressively dependent on the network. In general, the resources they need are not found outside the network.

In theory, given the fact that organizations deal with each other to obtain the necessary resources, control over such resources begins to play a key role in the relationship, because they create power over the other organizations, making them dependent (PFEFFER and SALANCIK, 1978). In other words, an organization can be influenced by another that holds substantial or exclusive control on the resources critical to the sustainability of this organization, which in this case is the network. In practice, this became clear in the empirical survey conducted. As the networks were able to deliver competitive advantages to their 
members by means of factors such as bargaining power, learning, innovation, and organizational legitimacy, the members became dependent on the network.

Another point to emphasize is that, even though companies seek strategies to prevent them from being controlled and losing their autonomy, dependence on the resources generated by a network should not be understood as damaging to the organization. If the network is the way in which the company obtains the critical resources for its survival and generates profit for its business, the fact that this company is dependent on the network becomes a reason for companies to commit themselves and collaborate even more for the success of the companies' actions undertaken by the network. For Gardet and Mothe (2012), dependence arises from the company's need to maintain a collaborative relationship to achieve its objectives. Thus, once the network is effective in providing the reach of these organizational objectives and providing a range of resources to reduce the uncertainty of the company in relation to the environment, it becomes an effective vehicle for the competitiveness of its member companies, and companies should work together to keep it going.

The results outlined in this study contribute to a more comprehensive approach on the mechanisms and factors that influence the understanding of the networks' evolution process, which become solid and operate as individual firms, independent from the member firms, as they evolve. Such tendency observed in this study leads to the understanding that networks may become organizations that, as any other business, require investments on key administrative areas, such as finances, marketing, and management of people and materials.

In addition, it broadens the spectrum for new possibilities of research, like: How does the power relationship that the network exerts on the members occur? Is the business industry where the network operates related to a greater or lesser dependence of the member firms? How to optimize the development of competitive advantages to maintain the member firms in the network? 


\section{REFERENCES}

ANDRÉ, M. R. D. L. Factores de sucesso nas redes interorganizacionais de carácter temporário. 2013. 289f. Thesis (Doctorate in Social Sciences) - Universidade Técnica de Lisboa, Lisboa, Portugal, 2013.

AHUJA, G. Collaboration networks, structural holes, and innovation: a longitudinal study. Administrative Science Quarterly, v. 45, p. 355-425, 2000.

ALBERS, $S$. The design of alliance governance systems. Köln: Kölner Wissenschaftsverlag, 2005.

ANDERSEN, P. H.; MEDLIN, C. J. Transient commitments and dynamic business networking. Industrial Marketing Management, v. 58, n. 1, p. 11-19, 2016.

ANDERSON J. C.; NARUS, J. A. A model of distributor firm and manufacturer firm working partnerships. Journal of Marketing, v. 54, n. 1, p. 42-58, 1990.

ANDRÉSEN, E.; LUNDBERG, H.; ROXENHALL, T. Designing for commitment in regional strategic networks. Management Research Review, v. 35, n. 6, p. 531-552, 2012.

BARDIN, L. Análise de conteúdo. Lisboa: Edições 70, 2010.

CARVALHO, J. F. et al. A cooperação entre redes de pequenas empresas: antecedentes, etapas e resultados da estratégia de intercooperação. REGEPE - Revista de Empreendedorismo e Gestão de Pequenas Empresas, v. 7, n. 1, p. 35-70, 2018.

CASTRO, M.; BULGACOV, S.; HOFFMANN, V. E. Relacionamentos interorganizacionais e resultados: estudo em uma rede de cooperação horizontal da região central do Paraná. Revista de Administração Contemporânea (RAC), v. 15, n. 1, p. 25-46, 2011.

CENTENARO, A.; LAIMER, C. G. Relações de cooperação e a competitividade no setor supermercadista. Revista Brasileira de Gestão de Negócios, v. 19, n. 63, p. 65-81, 2017.

CONKLIN, D.; TAPP, L. A rede criativa. In: CHOWDHURY, S. Administração do século XXI: o estilo de gerenciar hoje e no futuro. São Paulo: Pearson Education, 2003. p. 220-234.

DE ROLT, C. R.; DIAS, J. D. S.; PEÑA, F. T. G. Network analysis as a management tool for inter-organizational projects. Gestão \& Produção, v. 24, p. 266-278, 2017.

DEBOÇÁ, L. P.; MARTINS, R. S. Vantagens Competitivas Originadas dos Relacionamentos Horizontais em Aglomerações Produtivas: percepções de atores locais. Revista Brasileira de Gestão de Negócios, v. 17, n. 56, p. 1025-1043, 2015.

DICKEL, P.; HÖRISCH, J.; RITTER, T. Networking for the environment: The impact of environmental orientation on start-ups' networking frequency and network size. Journal of Cleaner Production, v. 179, p. 308-316, 2018.

DIMAGGIO, P. J.; POWELL, W. W. Institutional isomorphism and collective rationality in organizational fields. American Sociology Review, v.48, p.147-160, 1983.

DIRKS, K. T. The Effects of Interpersonal Trust on Work Group Performance. Journal of Applied Psychology, v.84, p.445-455, 1999.

FLICK, U. Introdução à pesquisa qualitativa. 3a ed. São Paulo: Artmed, 2009.
GARDET, E.; MOTHE, C. SME dependence and coordination in innovation networks. Journal of Small Business and Enterprise Development, v. 19, n. 2, p. 263-280, 2012.

GRAY, B. Assessing interorganizational collaboration: multiple conceptions and multiple methods. In: FAULKNER, D.; ROND, M. (Eds.) Cooperative strategy: economics, business and organizational issues. London: Oxford University Press, 2000. p. 243-260.

GULATI, R.; SYTCH, M. Dependence Asymmetry and Joint Dependence in Interorganizational Relationships: Effects of Embeddedness on a Manufacturer's Performance in Procurement Relationships. Administrative Science Quarterly, v. 52, n. 1, p. 32-69, 2007.

GUNDLACH, G. T.; ACHROL, R. S.; MENTZER, J. T. The structure of commitment in exchange. Journal of Marketing, v. 59, n. 1, p. 78-92, 1995.

HERNANDEZ, E.; SHAVER, J. M. Network Synergy. Administrative Science Quarterly, 2018.

HUMAN, S. E.; PROVAN, K. G. Legitimacy Building in the Evolution of Small Firm Networks: A Comparative Study of Success and Demise. Administrative Science Quarterly, v. 45, p. 327-365, 2000.

IDREES, I. A.; VASCONCELOS, A. C.; ELLIS, D. Clique and elite: interorganizational knowledge sharing across five star hotels in the Saudi Arabian religious tourism and hospitality industry. Journal of Knowledge Management, 2018.

ISETT, K. R. et al. Networks in public administration scholarship: understanding where we are and where we need to go. Journal of Public Administration Research and Theory, v. 21, n. 1, p. 157173, 2011.

JARILLO, J. C. On strategic networks. Strategic Management Journal, v. 9, n. 1, p. 31-41, 1998.

KLEIN, L. L.; PEREIRA, B. A. D. Contribuições para a gestão de redes interorganizacionais: fatores determinantes para a saída de empresas parceiras. Read: Revista Eletrônica de Administração, v. 20, n. 2, p. 305-340, 2014.

KLEIN, L. L.; PEREIRA, B. A. D. The survival of interorganizational networks: a proposal based on resource dependence theory. Revista de Administração Mackenzie, v. 17, n. 4, p. 153-175, 2016.

KNOBEN, J. et al. What do they know? The antecedents of information accuracy differentials in interorganizational networks. Organization Science, v. 2, p. 471-488, 2018.

KOGUT, B. Joint-Ventures: theoretical and empirical perspectives. Strategic Management Journal, v. 9, n. 4, p. 312-332, 1988.

LEWICKI, R.J.; BRINSFIELD C. Measuring trust beliefs and behaviours. In: LYON F; MÖLLERING, G.; SAUNDERS, M. (eds) Handbook of research methods on trust. Cheltenham: Edward Elgar, 2011. p. 29-39.

MCGUIRE, M. Collaborative public management: Assessing what we know and how we know it. Public Administration Review, v. 66, n. 1, p. 33-43, 2006.

MILWARD, H. B.; PROVAN, K. G. A manager's guide to choosing and using collaborative networks: IBM center for the business of government. IBM Report on the Business of Government, 2006. 
MOELLER, K. Partner selection, partner behavior, and business network performance: An empirical study on German business networks. Journal of Accounting \& Organizational Change, v. 6, n. 1, p. 27-51, 2010.

OLIVEIRA, W. S. et al. Gestão de Custos Interorganizacionais: uma pesquisa bibliométrica com base em publicações nacionais. RAGC Revista de Auditoria, Governança e Contabilidade, v. 4, n. 16, 2016.

OLSON, M. A lógica da ação coletiva. São Paulo: EDUSP, 1999.

PAQUIN, R. L.; HOWARD-GRENVILLE, J. Blind dates and arranged marriages: Longitudinal processes of network orchestration. Organization Studies, v. 34, n. 11, p. 1623-1653, 2013.

PEREIRA, B. A. D. et al. Desistência da cooperação e encerramento de redes interorganizacionais: em que momento essas abordagens se encontram? RAI - Revista de Administração e Inovação, v. 7, n. 1, p. 62-83, 2010.

PERROW, C. Complex organizations: a critical essay. New York: McGraw-Hill, 1998.

PERRY, M. L.; SENGUPTA, S.; KRAPFEL, R. Effectiveness of horizontal strategic alliances in technologically uncertain environments: are trust and commitment enough? Journal of Business Research, v. 57, p. 951-956, 2004.

PFEFFER, J.; SALANCIK, G. R. The External Control of Organizations: A Resource Dependence Perspective. New York: Harper and Row, 1978.

POPP, J. et al. Inter-organizational networks: A critical review of the literature to inform practice. Washington: IBM's Business of Government center, 2014.

PROVAN, K. G.; HUANG, K. Resource tangibility and the evolution of a publicly funded health and human services network. Public Administration Review, v. 72, n. 3, p. 366-375, 2012.

PROVAN, K.; KENIS, P. Modes of network governance: structure, management and effectiveness. Journal of Public Administration Research and Theory, v. 18, n. 2, p. 229-252, 2008.

PROVAN, K. G.; LEMAIRE, R. H. Core concepts and key ideas for understanding public sector organizational networks: using research to inform scholarship and practice. Public Administration Review, v. 72 , n. 5, p. 638-648, 2012.

PROVAN, K. G.; SYDOW, J. Evaluating Interorganizational Relationships. In: COPPER, S. et al. (Eds.). Handbook of Interorganizational Relations. Oxford: OUP, 2009.

RIBEIRO, F.; COLAUTO R. D. The Relationship Between Board Interlocking and Income Smoothing Practices. Revista Contabilidade \& Finanças, v. 27, n. 70 , p. 55-66, 2016.
RICHARDSON, R. J. Pesquisa social: métodos e técnicas. 3. ed. São Paulo: Atlas, 1999.

RING, P. S.; VAN DE VEN, A. H. Developmental processes of cooperative interorganizational relationships. Academy of Management Review, v. 19, n. 1, p. 90-118, 1994.

ROXENHALL, T. Network structure and network commitment in innovation networks. World Journal of Management, v. 3, n. 1, p. 60-74, 2011.

SADOWSKI, B.; DUYSTERS, G. Strategic technology alliance termination: an empirical investigation. Journal of Engineering and Technology Management, v. 25, p. 305-320, 2008.

SEATON, C. L. et al. Factors that impact the success of interorganizational health promotion collaborations: A scoping review. American Journal of Health Promotion, n. 32, v. 4, p. 1095-1109, 2018

SCHULZ, K.; GEITHNER, S. Between exchange and development: Organizational learning in schools through inter-organizational networks. Learning Organization, v. 17, n. 1, p. 69-85, 2010.

SCHUMPETER, J. A. Theorie der wirtschaftlichenentwicklung. Leipzig: Duncker e Humblot, 1911.

SELLTIZ, C.; WRIGHTSMAN, L. S.; COOK, S. W. Métodos de pesquisa nas relações sociais. São Paulo: Herder, 1972.

SHIPILOV, A. V.; ROWLEY, T. J.; AHARONSON, B. S. When do network matter? A study of tie formation and decay. In: SILVEMAN, D. (Ed.). Ecology and strategy. United Kingdom: Emerald Group, 2006. p. 481-515.

SUCHMAN, M. C. Managing legitimacy: strategic and institutional approaches. Academy of Management Journal, v. 20, n. 3, p. 571 610, 1995.

TUBIN, D.; LEVIN-ROZALIS, M. Interorganizational cooperation: the structural aspect of nurturing trust. International Journal of Public Sector Management, v. 21, n. 7, p. 704-722, 2008.

$X I A$, J. et al. Alliance formation in the midst of market and network: Insights from resource dependence and network perspectives. Journal of Management, v. 44, n. 5, p. 1899-1925, 2018.

WAARDEN, F. V. Emergence and development of business interest associations: an example from The Netherlands. Organization Studies, v. 13, n. 4, p. 521-561, 1992.

WESTERLUND, M.; RAJALA, R. Learning and innovation in interorganizational network collaboration. Journal of Business \& Industrial Marketing, v. 25, n. 6, p. 435-442, 2010. 
Leander Luiz Klein

ORCID: https://orcid.org/0000-0001-6075-6107

Doutor em Administração pela Universidade Federal de Santa Maria (UFSM); Professor Adjunto na Universidade Federal de Santa Maria (UFSM), Palmeira das Missões - RS, Brasil. E-mail: kleander88@gmail.com

Breno Augusto Diniz Pereira

ORCID: http://orcid.org/0000-0001-7387-5033

Doutor em Administração pela Universidade Federal do Rio Grande do Sul (UFRGS); Professor Adjunto na Universidade Federal de Santa Maria (UFSM), Santa Maria - RS, Brasil. E-mail: brenodpereira@gmail.com

Cad. EBAPE.BR, v. 17, Special Edition, Rio de Janeiro, Nov. 2019. 